\section{Sertraline-induced hyponatremia in the elderly}

The hyponatremic state affects approximately 3\%-5\% of in-hospital patients. ${ }^{1}$ Among the various etiologies of this state is the syndrome of inappropriate antidiuretic hormone (SIADH), which is characterized by a euvolumic state with low plasma osmolality and an inappropriately raised urinary osmolality. Multiple conditions are implicated in the genesis of this osmoregulatory disorder. ${ }^{2}$ Among them, drugs of various classes have been found to cause SIADH. The selective serotonin reuptake inhibitors (SSRIs), which are frequently used to treat depression, are included in this group. ${ }^{3}$

\section{Case report}

We report a case of a 78-year-old hypertensive male, well controlled on telmisartan $40 \mathrm{mg}$ and amlodipine $5 \mathrm{mg}$. He presented with gradual onset drowsiness and anorexia for the previous 3 days. There was no history of fever, headache, seizures or focal neurological deficit, and on examination, his $\mathrm{BP}$ was $150 / 80 \mathrm{~mm} \mathrm{Hg}$, his pulse rate was 88 beats/min and was regular with occasional ventricular ectopics, his Glasgow coma scale score was 9 and he was euvolumic. Baseline evaluation revealed serum sodium of $100 \mathrm{mmol} / \mathrm{L}$, serum potassium of $3.8 \mathrm{mmol} / \mathrm{L}$, plasma osmolality was $265 \mathrm{mosm} / \mathrm{L}$ and urinary sodium was $>40 \mathrm{mmol} / \mathrm{L}$. Renal and thyroid functions were normal. A diagnosis of SIADH was considered. The causative agent was found to be the SSRI, sertraline. The patient had been taking $50 \mathrm{mg}$ daily for 7 days because of depression. He was managed by fluid restriction and 3\% normal saline and the sertraline was withdrawn. The patient began showing improvement after 48 hours and was discharged on the fifth day with a serum sodium of $135 \mathrm{mmol} / \mathrm{L}$.

\section{Discussion}

Depression is commonly seen in clinical practice, especially in elderly patients. SSRIs are the preferred treatment choice because of their better tolerability and safety; however, serious adverse effects have been reported. One of them, as described in the present case, is severe hyponatraemia. A possible explanation for SSRI-induced SIADH is the stimulatory effect of serotonin on ADH secretion via the $5 \mathrm{HT}_{1}$ and $5 \mathrm{HT}_{2}$ receptors. $^{4}$

In our case, the occurrence of hyponatremia 7 days following the initiation of sertraline, and the reversal of this biochemical abnormality and improvement in clinical profile after discontinuation of the drug, supports this causative link. Hyponatremia occurring as an adverse effect of an SSRI is under-diagnosed because most of the cases are asymptomatic and hence go unnoticed.

\section{Conclusion}

Sertraline-induced hyponatraemia, although relatively uncommon, is an important clinical problem with a serious outcome. Its use in clinical practice demands extra vigilance regarding dyselectrolytemia, especially in elderly patients.

\section{N.K. Agrawal, MD, DM (Endocrinology) Amit Rastogi, MD \\ Rakesh Goyal, MD}

S.K. Singh, MD, DM (Endocrinology) Department of Endocrinology and Metabolism

Institute of Medical Sciences

Banaras Hindu University

Varanasi, India

\section{References}

1. Adrogue HJ, Madias NE. Hyponatremia. N Engl J Med 2000;342:1581-9.

2. Belton K, Thomas SH. Drug-induced syndrome of inappropriate antidiuretic hormone secretion. Postgrad Med J 1999;75:509-10.

3. Kirby D, Ames D. Hyponatraemia and selective serotonin re-uptake inhibitors in elderly patients. Int J Geriatr Psychiatry 2001;16:484-93.

4. Chan TY. Drug-induced syndrome of inappropriate antidiuretic hormone secretion. Causes, diagnosis and management. Drugs Aging 1997;11:27-44.

\begin{abstract}
Letters will be considered for publication if they relate to topics of interest to emergency physicians in urban, rural, community or academic settings. Letters responding to a previously published CJEM article should reach CJEM head office in Vancouver (see masthead for details) within 6 weeks of the article's publication. Letters should be limited to 400 words and 5 references. For reasons of space, letters may be edited for brevity and clarity.
\end{abstract}

Les lettres seront considérées pour publication si elles sont pertinentes à la médecine d'urgence en milieu urbain, rural, communautaire ou universitaire. Les lettres en réponse à des articles du JCMU publiés antérieurement devraient parvenir au siège social du JCMU à Vancouver (voir titre pour plus de détails) moins de six semaines après la parution de l'article en question. Les lettres ne devraient pas avoir plus de 400 mots et cinq références. Pour des raisons d'espace et par souci de concision et de clarté, certaines lettres pourraient être modifiées. 